\title{
Using thought mapping and structured stories to decrease HIV risk behaviors among cocaine injectors and crack smokers in the South of Brazil A utilização do mapeamento coginitivo e de histórías estruturadas para diminuir comportamentos de risco para a contaminação pelo HIV entre consumidores de cocaína injetável e de crack no Sul do Brasil
}

\author{
Flavio Pechansky, ${ }^{1}$ Diego Garcia Bassani, ${ }^{2}$ Lisia von Diemen, ${ }^{1}$ Félix Kessler, ${ }^{1}$ \\ Carl G Leukefeld, ${ }^{3}$ Hilary L Surratt, ${ }^{4}$ James A Inciardi, ${ }^{4}$ Steven S Martin ${ }^{4}$
}

\begin{abstract}
Objectives: To compare changes in AIDS knowledge and risk behaviors among Brazilian cocaine users in an intervention trial. Method: 119 participants were randomly assigned to either a standard or a standard plus "thought mapping" intervention, and re-interviewed 2 and 8 weeks after intake using standardized data collection instruments. Intervention effects were examined using generalized estimated equation model. Results: Significant increases in AIDS knowledge and condom use were observed in the experimental group, as well as significant changes in the subscores for sexual and drug risks. The experimental intervention was less successful in decreasing mean days of cocaine use when compared to the standard. Conclusion: Although not robust, the findings nevertheless suggest that components of the experimental thought-mapping model might be useful in combination with other approaches.
\end{abstract}

Descriptors: HIV; Substance related disorders; Crack cocaine/injections; Psychosocial impact; Intervention studies

\begin{abstract}
Resumo
Objetivos: Comparar as mudanças em conhecimento sobre AIDS e comportamentos de risco em usuários de cocaína brasileiros submetidos a uma intervenção experimental. Método: 119 sujeitos foram aleatoriamente designados para uma intervenção padrão ou uma intervenção padrão adicionada a um "mapa cognitivo", e re-entrevistados duas e oito semanas após admissão no estudo, utilizando-se instrumentos de coleta padronizados. Os efeitos da intervenção foram examinados utilizando modelo de equações de estimação generalizadas. Resultados: Foram observados aumentos significativos no conhecimento sobre AlDS e uso de preservativos no grupo experimental, bem como modificações significativas nos subescores para risco sexual e uso de drogas. A intervenção experimental teve menos sucesso em diminuir dias de uso de cocaína quando comparada com a intervenção padrão. Conclusão: Apesar de não serem robustos, os achados sugerem que os componentes do modelo de mapa cognitivo experimentados poderiam ser úteis em combinação com outras abordagens.
\end{abstract}

Descritores: HIV; Transtornos relacionados ao uso de substâncias; Cocaína crack/injeções; Impacto psicossocial; Estudos de intervenção

1 Center for Drug and Alcohol Research, Universidade Federal do Rio Grande do Sul (UFRGS), Porto Alegre (RS), Brazil

2 Centre for Addiction and Mental Health, University of Toronto, Canada

3 Center on Drug and Alcohol Research, University of Kentucky, USA

4 Center for Drug and Alcohol Studies, University of Delaware, USA

Financing: This research was supported in part by HHS Grant \# 1 R01 DA11611 from the National Institute on Drug Abuse

Conflict of interests: None

Submitted: August 9, 2006

Accepted: November 30, 2006
Correspondence

Flavio Pechansky

Director, Center for Drug and Alcohol Research, UFRGS

Rua Ramiro Barcelos 2350, sala 2201F

90035-003 Porto Alegre, RS, Brazil

Phone: (55 51) 3330-5813 Fax: (55 51) 3332-4240

E-mail: fpechans@uol.com.br and cpad.fm@terra.com.br 


\section{Introduction}

Cocaine use emerged as a public health problem in Brazil during the early $1980 \mathrm{~s}^{1,2}$ Initially, the primary route of administration was intranasal, but by the early 1990 s a number of users were injecting cocaine and sharing syringes, which contributed to the spread of HIV and AIDS. ${ }^{3,4}$ Crack-cocaine also began to appear during the early 1990s, particularly in São Paulo and other large urban areas of Brazil.5,6 However, crack use has been effectively documented in Porto Alegre the fifth largest city in Brazil and southernmost state capital only since $2000 .^{7}$

Crack use has been accompanied by a shift in the epidemiology of the AIDS epidemic in Brazil, with the relative number of new cases of HIV attributable to cocaine injection, particularly among women, which is related to unprotected heterosexual contact. This trend has contributed substantially to the feminization of the AIDS epidemic throughout Brazil, and in the city of Porto Alegre ${ }^{8}$ (Inciardi et al., in press ${ }^{1}$ ). However, there have been few studies in Brazil which targeted crack users, ${ }^{7,9,10}$ and they have only been able to describe the basic demographic profile of these subjects, as well as evidence of an increase in the incidence of such drug use in restricted areas. This may be associated with a cultural belief among public health and other Brazilian health professionals that crack users: 1) are difficult to treat; 2) leave treatment prematurely; and 3) do not respond to preventive measures even though harm reduction approaches have proven successful. ${ }^{11-13}$

Although declining, cocaine injection has been welldocumented as one of the major risk factors for HIV infection among drug users in southern Brazil. ${ }^{8,14}$ Lower levels of education and income have also been demonstrated to be associated with HIV/AIDS among cocaine and crack users, and both factors have been related to limited access to prevention information. ${ }^{15}$ However, given the growth of the crack epidemic and the continuing spread of HIV among individuals living in the 'favelas' (slums) and other marginalized urban communities, it is important to adapt existing sciencebased intervention approaches to the cultural context of poor hard-to-reach Brazilians. It was within this context that a thought mapping/"structured stories/thought-mapping" approach to HIV risk reduction was examined in Porto Alegre.

The thought mapping/Structured stories/Intervention The thought-mapping/structured stories approach is grounded in the Stages of Change Transtheoretical Model, ${ }^{16,17}$ and was developed by researchers at the University of Kentucky and the University of Delaware. The adapted intervention for Brazil is described elsewhere. ${ }^{18}$ The intervention has three interrelated parts: 1) the National Institute on Drug Abuse (NIDA) Standard HIV Intervention, ${ }^{19}$ which has been shown to be effective in changing short-term HIV related risk behaviors; ${ }^{20}$ 2) and the "thought mapping," which has been successful in reducing substance abuse in chronic drug using populations; ${ }^{21,22}$ 3) "structured stories," which relate directly to the cultural context of the target population. ${ }^{23-25}$

\section{The NIDA Standard Intervention}

The initial NIDA Standard was a two session cue-card based intervention developed and modified by the NIDA staff and the Principal Investigators as part of the AIDS Cooperative Agreement in the early 1990s. It was later revised to incorporate more information on crack cocaine use and sexual risks for HIV, ${ }^{19}$ and subsequently adapted for use with drug abusers in Brazil. ${ }^{26}$
Session 1 of the intervention includes HIV pre-test counseling and gives information on: HIV disease, transmission routes, risky behaviors, indirect sharing, risks associated with crack and other cocaine use, male and female condom use, communication with sexual partners, stopping unsafe sexual practices, cleaning and bleach disinfection of injection equipment, disposal of hazardous waste material, stopping unsafe drug use, and the benefits of drug treatment. In addition, the correct use of male and female condoms and proper needle cleaning techniques are demonstrated and rehearsed. Written information about HIV, service referrals, and hygiene kits containing risk reduction supplies are distributed, and voluntary HIV testing is offered to all participants. A second session, about 2 weeks later, discusses HIV test results and provides appropriate referrals.

\section{Thought mapping}

Thought mapping is a visual technique that targets personal drug using and risky sexual behaviors, ${ }^{27}$ and connects an individual's thoughts and feelings to a problem behavior or experience. The participants' behaviors are visually recorded on paper using a pre-formatted map. ${ }^{24}$ Mapping provides an approach to help participants relate what came before antecedents - high risk behavior, as well as their own thoughts and feelings associated with high risk situations, the potential consequences of their own behavior, and alternative behavioral responses. The technique can help participants identify a problem and consider lower risk solutions to the problem.

\section{Structured stories}

Structured stories are directed and scripted narratives that target specific risk situations in order to help participants explore the connections between behavioral choices and subsequent outcomes. Interventionists use structured stories to help participants understand the relationships between specific behaviors, feelings and thoughts, and their consequences, and to consider behavioral alternatives. ${ }^{25}$ Structured stories allow participants to practice specific skills with behavioral "rehearsals", ${ }^{24,28}$ and to explore alternative solutions for problem or risky behaviors that may facilitate contemplation or action according to the Transtheoretical Model of Change. ${ }^{29}$ Clark and Leukefeld, when designing and implementing the intervention described that "most clients perceived [the technique] as a helpful learning process that used multiple treatment strategies and presented an alternative to 12-step programs." Using structured stories that are similar to those of the participants, individuals are cued to think about personal situations of risk, and the structured format assists participants in evaluating their own behaviors. ${ }^{23}$

For the purpose of this study, we hypothesized that both interventions would provide an increase in the overall knowledge about HIV/AIDS, but that the experimental intervention would further increase this knowledge due to its structure and focus. Also, it was the author's goal to determine whether an adaptation of a more structured intervention based on storytelling - the thought mapping approach - would be able to decrease overall drug consumption in this sample. This paper presents the results of the first field trial of this adapted thought mapping intervention with urban, out-oftreatment cocaine injectors and crack users in Brazil.

\section{Method}

A quasi-experimental clinical trial compared the thought mapping/structured story intervention to a "treatment as 
usual" condition - the NIDA Standard Intervention, in a sample of male cocaine users. The NIDA Standard Intervention was adopted as the regular protocol for HIV pre- and post-test counseling at Porto Alegre's Serological Orientation and Support Centers (Centros de Apoio e Orientação Sorológica - COAS) when it became available in Brazilian Portuguese in 1999. ${ }^{11}$

The trial was conducted at the local COAS, which is part of a system of public health centers that serve indigent populations in Porto Alegre. These centers provide free pregnancy testing, HIV testing, and a range of other testing and health care services. The COAS centers are strategic locations to conduct studies with drug abusers for a variety of reasons that include: 1) the overwhelming majority of COAS clients are from Porto Alegre's many favelas - places with high concentrations of drug users mostly of cocaine, marijuana, and crack; and 2) the COAS catchment areas include most of the city of Porto Alegre.

The intervention focused on the following primary outcomes: knowledge about HIV/AIDS; drug use; condom use; and readiness to change.

A purposive sample of 131 male cocaine users was recruited during 2003 and 2004 for the thought mapping/structured story intervention. Since this was a pilot study to evaluate feasibility for a larger grant application, no previous estimate of sample size was conducted. Inclusion criteria were: male, at least 18 years of age, having had sex at least once during the 30 days prior to interview, having smoked crack or injected cocaine at least once during the 30 days prior to interview, and being residents of the metropolitan area of Porto Alegre. Exclusion criteria were severe drug intoxication or an active psychiatric disorder that would preclude data collection and follow-up.

A possible sample of 131 subjects was screened. Of these, 119 met the inclusion criteria and were included in the final sample (57 in the experimental group, and 62 in the control group). Since 5 (4.2\%) clients were lost to follow-up, 114 cases were included in the final analyses. These 5 cases were not different from the whole sample in relation to income (family, illegal and individual), age, work, schooling and days using crack or injected cocaine in the previous 30 days. Statistical tests were conducted to confirm that the 5 cases excluded do not interfere in the conclusions of the study.

\section{Procedures}

Participants were invited to the COAS by trained street recruiters who were employed in a city harm reduction and needle exchange program. Active cocaine users, defined as selfreported injected cocaine or crack use in the previous 30 days were asked to participate in the study. Urine tests revealed that over half (57.1\%) were current users by testing positive for cocaine. Participants were assigned to the experimental and control groups (intervention as usual + thought mapping/ structured or "intervention as usual"), which was blocked by the day of the week participant inclusion into either experimental or control would be done depending on the day of the week the subjects arrived to the center due to study logistics (interventionists for the experimental sessions and control sessions were not available full time at the test site). This was previously tested and no difference was found due to assignments on specific days. The interventions were conducted by an occupational therapist trained by the authors.

The study included the following specific procedures:

Session 1. After eligibility was confirmed, project staff explained the voluntary and confidential nature of the study, as well as the benefits of the intervention and the small financial compensation for the time of study subjects' participation. Written consent was obtained using procedures approved by Institutional Review Boards in Brazil and the United States. Each participant then completed a short questionnaire, which included items for follow-up location, and participated in a structured baseline interview. Afterwards, each client participated in the NIDA Standard Intervention with pre- and post-test counseling, under the guidelines of the Brazilian Ministry of Health. Blood specimens were collected for HIV testing. The control group completed the intervention. The experimental group also received the thought mapping/structured story intervention. At the end of either the Standard or thought mapping/structures story intervention, a second appointment was scheduled 2 weeks later, for all participants to receive HIV test results and post-HIV-test counseling. Only the thought mapping/ structured story participants received a second intervention session.

Session 2. Post- test counseling was provided for both groups, and a follow-up appointment was scheduled 4 weeks later. In addition, subjects who participated in the intervention were encouraged to analyze their individual thought maps, and to develop strategies to avoid future drug use and sexual risk behaviors.

Session 3. At the third session, thought mapping/ structured story participants received an additional booster session, which reinforced Session 2. Both experimental and control participants were also re-interviewed to assess changes in knowledge, attitudes, and risk behaviors.

\section{Instrumentation}

Instrumentation included:

1) The standard identification form used by the Porto Alegre Center for Drug and Alcohol Research that includes questions about baseline information, demographics, signed informed consent, and a checklist for the interviewer to confirm case validity. ${ }^{29,30}$

2) Risk Assessment Battery (RAB) - Third Brazilian Version. This instrument includes questions to assess drug use in the previous 30 days and 6 months, as well as risk situations and behaviors associated with HIV infection. Specific questions focus on the lifetime number of sex partners, frequency of condom use, number of times a subject paid money for sex, the number of times a subject injected, and concerns regarding HIV infection. Originally designed by Metzger et al. (1993), the RAB is easy to administer as a self-reported questionnaire, which provides a general risk score in addition to two subscores for drug related or sex risk related behaviors. The RAB has been used in Porto Alegre ${ }^{8,31}$ and Rio de Janeiro, Brazil. ${ }^{32}$ Since previous studies conducted with this version of the RAB did not provide sufficient evidence of its psychometric characteristics with regard to overall score and subscores, the authors decided to use individual questions and clusters of questions from the questionnaire that have proven to be appropriate for its use in the process of its adaptation to Brazilian Portuguese. ${ }^{28}$

3) AIDS Information Questionnaire. ${ }^{33}$ This instrument contains a 14-item scale adapted from Kelly et al. that measures AIDS knowledge. The AIDS knowledge scale has demonstrated test-retest reliability coefficient of 0.84 , and an internal consistency measure of 0.74 . In addition, the 
scale has evidenced high construct validity. This questionnaire has been used in Delaware studies ${ }^{34}$ and has been adapted to use in Brazil.

4) Section B of the NIDA's Risk Behavior Assessment, which has been used in a variety of countries, including the U.S., Brazil, Australia, South Africa, and the Caribbean Basin.

5) The URICA questionnaire, a 32-item instrument that measures 4 statistically and well-defined stages of change utilizing 8 questions for each stage: precontemplation, contemplation, action, and maintenance. It takes about 10 minutes to complete, has good internal consistency, concurrent and predictive validity, as has been recently reviewed by Castro and Passos. ${ }^{35,36}$ Carney and Kivlahan ${ }^{37}$ have documented internal consistency of the scale between 0.80 and 0.84 , and Velasquez et al. ${ }^{38}$ found $a$ Cronbach's alpha for a Readiness scale of 0.91 .

6) Urine tests (Assays for Cocaine metabolite. Ontrak Teststik. Roche Diagnostics)

Data management and analysis included the following specific tasks: Each questionnaire was individually checked for errors, corrected as needed, and entered into a database by project staff. Interim analyses were performed for quality control during data collection. After consistency reviews and coherence checks of the data, quantitative variables were presented in contingency tables which included frequencies. Means and standard deviations were used to describe variables normally distributed. Median and interquartile range was used to describe non-normally distributed variables. For baseline comparisons, statistics tests utilized were chi-square, t-test for independent samples and Wilcoxon-Mann-Whitney test.

The data were analyzed using generalized estimated equations (GEE) Stata 8.0.39,40 Generalized estimated equations estimate marginal effects taking into account the dependence among the units nested in clusters with the advantage of estimating effects more efficiently for taking into consideration the dependence structure of the data. The correlation matrices were examined to specify outcome correlation structure within subjects and within group over time, so that appropriate models accounting for the correlation of the outcomes could be estimated. The link functions for each of the models were selected after taking into account the working correlation structure and the approximate distribution family of the outcome variables.

For supposed normally distributed outcomes, the "identity" was used as the link function, and interpretation did not involve transformation of the estimates. Therefore, each unit change in the exposure corresponds to a unit change in the mean of outcome. When the outcome was count data - i.e. Poisson distribution - the chosen link function was the logarithm of the mean as the regression coefficient as a representation of the expected change in the log of the mean of the dependent variable for each change in a covariate. In these situations, the exponential transformation of the coefficient estimates the relative risk towards the outcome. The significance level for all tests was set at $\alpha=0.05$. The association of the intervention with the outcomes was modeled through GEE to estimate raw and adjusted coefficients and respective 95\% confidence intervals. Dependent variables used were: AIDS information, days of consumption of any cocaine, crack and cocaine injection in the previous 30 days, used crack in the previous 30 days, used cocaine injected in the previous 30 days, condom use and readiness to change sex and drug behavior.

\section{Results}

Due to the blocked intervention assignment, exhaustive checks for comparability of the groups were performed. There were no statistically significant differences between the two groups on any of the demographic characteristics. In general, $52.1 \%(n=62)$ of the overall sample was less than 30 years old, 58\% ( $n=69)$ was non-white, 56.3\% ( $n=67)$ had at least a seventh grade education; $40.3 \%(n=48)$ was married, and $43.7 \%(n=52)$ had earnings of US\$ 90 or less per month. Groups were not different in crack use and injecting cocaine in the previous 30 days, as well as snorted cocaine [45.6\% $(n=26)$ in the experimental and 58.1\% $(n=36)$ in the control group, $p=0.17]$. Demographic findings and cocaine use are summarized in Table 1.

A high seroprevalence rate was found in both the experimental $(49.1 \%)$ and control $(40.3 \%)$ groups, with no significant

Table 1 - Baseline characteristics and comparisons between groups

\begin{tabular}{|c|c|c|c|c|c|}
\hline \multicolumn{2}{|c|}{ Demographic characteristics } & \multirow{2}{*}{$\begin{array}{c}\begin{array}{c}\text { Total } \\
(\mathbf{n}=119)\end{array} \\
100.0 \%(119)\end{array}$} & \multirow{2}{*}{$\begin{array}{c}\begin{array}{c}\text { Experimental } \\
(\mathbf{n}=\mathbf{5 7})\end{array} \\
100.0 \%(57)\end{array}$} & \multirow{2}{*}{$\begin{array}{c}\begin{array}{c}\text { Control } \\
(\mathbf{n}=\mathbf{6 2})\end{array} \\
100.0 \%(62)\end{array}$} & \multirow{2}{*}{$\begin{array}{c}p p \\
p \text { value } \\
1.00\end{array}$} \\
\hline Male & & & & & \\
\hline Age (30 or more years old) & & $47.9 \%(57)$ & $45.6 \%(26)$ & $50.0 \%(31)$ & 0.71 \\
\hline Race (Caucasian) & & $42.0 \%(50)$ & $43.9 \%(25)$ & $40.3 \%(25)$ & 0.71 \\
\hline Education (Seventh grade or less) & & $56.3 \%(67)$ & $59.6 \%(34)$ & $53.2 \%(33)$ & 0.30 \\
\hline Marital status (Married) & & $40.3 \%(48)$ & $42.1 \%(24)$ & $38.7 \%(24)$ & 0.85 \\
\hline \multirow[t]{2}{*}{ Employment } & Regular work & $43.7 \%(52)$ & $35.1 \%(20)$ & $51.6 \%(32)$ & 0.10 \\
\hline & Less than $\$ 90.00 /$ month & $40.3 \%(48)$ & $36.8 \%(21)$ & $43.5 \%(27)$ & 0.58 \\
\hline \multirow[t]{3}{*}{ Cocaine use - previous 30 days } & Just crack cocaine & $61.3 \%(73)$ & $56.1 \%(32)$ & $66.1 \%(41)$ & 0.09 \\
\hline & Just injected cocaine & $16.9 \%(20)$ & $24.6 \%(14)$ & $9.7 \%(6)$ & \\
\hline & Crack + injected cocaine & $21.9 \%(26)$ & $19.3 \%(11)$ & $24.2 \%(15)$ & \\
\hline \multirow{3}{*}{$\begin{array}{l}\text { Days of consumption in previous } 30 \\
\text { days }\end{array}$} & Any cocaine $¥$ & $4(3-10)$ & $3.5(2-9.5)$ & $5(3-14)$ & 0.15 \\
\hline & Injected only $¥$ & $3(1-10)$ & $3(1-9)$ & $4.5(1-10)$ & 0.80 \\
\hline & Crack only¥ & $14(4-24.5)$ & $12(4.5-20)$ & $14(4-25)$ & 0.52 \\
\hline \multicolumn{2}{|l|}{ AIDS information* } & $12.3 \pm 1.6$ & $12.5 \pm 1.5$ & $12.1 \pm 1.7$ & 0.13 \\
\hline \multicolumn{2}{|l|}{$\begin{array}{l}\text { Number of partners in the previous } \\
30 \text { days } ¥\end{array}$} & $1(1-3)$ & $1(1-3)$ & $1(1-2)$ & 0.39 \\
\hline \multicolumn{2}{|l|}{ Condom use in vaginal sex $¥$} & $70.8(0-100)$ & $100(21.25-100)$ & $45(0-100)$ & 0.02 \\
\hline \multicolumn{2}{|l|}{ Readiness to change sex behavior* } & $8.1 \pm 1.9$ & $8.0 \pm 1.8$ & $8.2 \pm 2.1$ & 0.69 \\
\hline \multicolumn{2}{|l|}{ Readiness to change drug behavior* } & $10.1 \pm 1.9$ & $10.3 \pm 1.7$ & $9.9 \pm 2.1$ & 0.269 \\
\hline
\end{tabular}

*Mean and standard deviation, $t$-test for independent samples; $¥$ Median and interquartile range, Wilcoxon-Mann-Whitney test 
difference between groups ( $p=0.36$ ), yielding an overall seroprevalence rate of $44.5 \%$. Different seroprevalence rates were found when IDUs and crack users were compared. Specifically, seroprevalence was $18.6 \%(n=8)$ for crack smokers who had not injected in the previous 6 months: seroprevalence was $81.3 \%(n=13)$ for crack smokers who had injected in the last 6 months,

Overall, the study retained a majority of subjects at the 2-week follow-up (95\% and $97 \%$ for the experimental and control groups ( $p=0.70$ ), and $98 \%$ and $95 \%$, respectively, for the second follow-up at 6 weeks from baseline interview. $(p=0.93)$.

Table 2 presents the unadjusted effects of the experimental intervention on several outcomes from the generalized estimated equations. AIDS information increased as a result of the intervention, with the mean number of correct answers being 1.1 points higher on average at follow-up, when compared to the control group. Condom use during vaginal sex also increased among those in the experimental intervention. Specifically, subjects used condoms during vaginal sex $29 \%$ more than the control group (Relative Risk 1.29 [1.12; 1.48]).

Unadjusted data suggest that crack use during the 30 days before the follow-up - measured by number of days of use was reduced over time, being about 25\% lower for experimental group, when compared to the control group. However, injected cocaine was not improved after the intervention; being $54 \%$ higher in the intervention group at the end of the trial, before proper adjustments for confounders. Both interventions were effective in reducing the number of sex partners; however, when comparing median and interquartile range, the experimental intervention showed significantly stronger effects. Condom use during vaginal sex increased by $29 \%$ after the intervention. Other outcomes also improved, although not significantly. These changes were days of use of any form of cocaine $(7 \%$ reduction in the mean number of days), and readiness to change drug behavior (0.14 increase in the mean score). Readiness to change sexual behaviors and number of sexual partners in the previous 30 days were unaffected or negatively affected by the intervention, although also not significantly.

The adjusted analysis is presented in Table 3. AIDS information improved in the experimental intervention, as shown previously, by 1.45 points in the mean score. The estimates of the effect of the intervention on this outcome were more pronounced after adjustment for previous participation in a harm reduction program. Prior participation in these programs might have been a confounder of the level of previous AIDS information clients could have at study entry.

Individuals in the thought mapping/structured stories intervention used cocaine $13 \%$ less frequently when compared to the control group over time. Nevertheless, the number of days of injected cocaine is significantly higher $(62 \%)$ in the intervention group over time when compared to the control group. The number of days of crack-cocaine use in the previous month was also higher in the intervention group, although the confidence interval was non-significant. The only other outcome that improved after controlling for potential confounders was condom use during vaginal sex, since individuals participating in the experimental intervention were $19 \%$ more likely to use condoms than controls.

\section{Discussion}

This study demonstrates the feasibility of conducting a quasiexperimental trial with very hard-to-reach out-of-treatment urban cocaine and crack users in Brazil. In addition, a high study retention rate was maintained from baseline to followup of 95 and $97 \%$. This rate is exceptionally high for South American studies of hard-to-retain subjects, and it is unusual to the best of the authors' knowledge, since articles about Latin and South American studies on the issue clearly describe the paucity of regular data collection, as well as a lack of continuous practices with regard to prevention efforts, such as harm reduction, even in countries where such endeavor is already being undertaken, like Brazil and Argentina. ${ }^{41,42}$ Since this study was completed at a relatively low cost, it also demonstrates the viability of short-term follow-up studies in South American urban settings. In summary, the main findings of this study were that there was a significant but discrete enhancement in the knowledge about AIDS in the experimental group, as well as an increase in condom use, and a significant decrease in crack use in that group. However, the intervention was not efficacious in positively modifying injection drug practices.

The high retention rate is related to the efficacy of the outreach recruiters who were either active or former drug users, as well as staff members of a well established and effective local harm reduction program. Besides being indigenous to the local recruiting areas, these recruiters had personal knowledge of drug using social networks, which were instrumental in finding and retaining subjects. At the same time, recruiting and following cases from these social networks may have affected the study results, since some of the subjects

Table 2 - Generalized estimated equation estimates for the association of the intervention with changes in the outcomes over follow-up times. Estimated coefficient interpretations vary according to the model distribution family. Control group and baseline are the equations' reference categories

\begin{tabular}{|c|c|c|c|c|}
\hline & $\begin{array}{c}\text { Estimate } \\
\text { (see estimate interpretation key) }\end{array}$ & Cl. & $\mathbf{P}$ & Estimate interpretation key \\
\hline AIDS information ** & 1.10 & $(0.61 ; 1.59)$ & $<0.001$ & Beta \\
\hline \multicolumn{5}{|l|}{ Days of consumption in previous 30 days } \\
\hline Any cocaine ${ }^{\star}$ & 0.93 & $(0.81 ; 1.06)$ & 0.295 & IRR \\
\hline Injected only* & 1.54 & $(1.24 ; 1.91)$ & $<0.001$ & IRR \\
\hline Crack only* & 0.75 & $(0.65 ; 0.83)$ & $<0.001$ & IRR \\
\hline Used crack in the previous 30 days* & 0.84 & $(0.61 ; 1.18)$ & 0.326 & IRR \\
\hline Cocaine injection in the previous 30 days $^{*}$ & 1.45 & $(0.84 ; 2.52)$ & 0.182 & IRR \\
\hline Number of partners in the previous 30 days* & 0.99 & $(0.79 ; 1.23)$ & 0.920 & IRR \\
\hline Condom use in vaginal sex* & 1.29 & $(1.12 ; 1.48)$ & $<0.001$ & IRR \\
\hline Readiness to change sex behavior** & -0.26 & $(-0.89 ; 0.37)$ & 0.422 & Beta \\
\hline Readiness to change drug behavior** & 0.14 & $(-0.34 ; 0.63)$ & 0.568 & Beta \\
\hline
\end{tabular}

*Poisson family; **Gaussian Family 
Table 3 - Adjusted effect of treatment to selected outcomes - each line represents the estimates obtained through an independently adjusted model with specifications presented under 'Family' and 'Link function' columns

\begin{tabular}{|c|c|c|c|c|}
\hline Outcome & $\begin{array}{c}\text { Estimate } \\
\text { (see estimate interpretation key) }\end{array}$ & $\mathrm{Cl}(95 \%)$ & $\mathbf{p}$ & $\begin{array}{c}\text { Estimate interpretation } \\
\text { key }\end{array}$ \\
\hline${ }^{1}$ AIDS information* & 1.45 & $(0.61 ; 2.28)$ & $<0.001$ & Beta \\
\hline \multicolumn{5}{|l|}{${ }^{2}$ Days of consumption in previous 30 days } \\
\hline Any Cocaine ${ }^{\star \star}$ & 0.87 & $(0.77 ; 0.99)$ & 0.003 & IRR \\
\hline Injection only*** & 1.62 & $(1.30 ; 2.02)$ & $<0.001$ & IRR \\
\hline Crack only ${ }^{\S}$ & 1.22 & $(0.98 ; 1.54)$ & 0.072 & IRR \\
\hline${ }^{2}$ Used crack in the previous 30 days ${ }^{£}$ & 0.78 & $(0.34 ; 1.78)$ & 0.560 & IRR \\
\hline${ }^{2}$ Cocaine injection in the previous 30 days ${ }^{€}$ & 1.07 & $(0.51 ; 2.23)$ & 0.863 & IRR \\
\hline${ }^{2}$ Number of partners in the previous 30 days ${ }^{*}$ & 1.01 & $(0.78 ; 1.31)$ & 0.923 & IRR \\
\hline${ }^{2}$ Condom use in vaginal sex ${ }^{\pi}$ & 1.19 & $(1.01 ; 1.40)$ & 0.002 & IRR \\
\hline${ }^{1}$ Readiness to change sex behavior ${ }^{\#}$ & -0.31 & $(-0.94 ; 0.31)$ & 0.323 & Beta \\
\hline${ }^{1}$ Readiness to change drug behavior ${ }^{\&}$ & 0.39 & $(-0.64 ; 1.41)$ & 0.805 & Beta \\
\hline
\end{tabular}

${ }^{1}$ Link function "Id" and family "Gaussian"; ${ }^{2}$ Link function: "Log" and family: "Poisson"

${ }^{*}$ Adjusted for harm reduction program (hrp) participation; ${ }^{* *}$ Adjusted for cocaine injection; ${ }^{* * *}$ Adjusted for hrp, age, and crack use; ${ }^{\S}$ Adjusted for hrp, cocaine injection, and age; ${ }^{£}$ Adjusted for hrp cocaine injection and age; $€$ Adjusted for "knows has HIV", cocaine injection and age; ${ }^{\sharp}$ Adjusted for "knows has HIV" cocaine injection, number of partners, regular partner and number of intercourses in the previous month; "Adjusted for "knows has HIV", age; number of partners; " Adjusted for "knows has HIV", cocaine injection and hrp

may have previously participated in other AIDS prevention interventions. This participation could have impacted the overall effect of the interventions, both experimental and control, since both groups would have less possibility to change in terms of acquisition of AIDS knowledge, for example, when compared to a non-biased sample.

It is important to note that the experimental intervention has not been compared to a "placebo" control. In fact, it was compared to a well developed and structured intervention the NIDA Standard adapted to the Brazilian culture ${ }^{26}$ - and this may have lowered the differences between groups. Since the NIDA Standard Intervention adapted to Brazil has been in use for about 6 years, it is possible that it "fits better" with participant needs than the newly developed intervention, mostly because it has been exposed to much more testing and adaptation than the newly proposed thought mapping approach. Also, thought mapping is also a more complex intervention that demands more cognitive effort by the subject.

The sample's representativeness of drug users in Porto Alegre is not clear, as it is typical of studies of such nature. Individuals from these poverty pockets are at the lower level of the socioeconomic pyramid in Brazil, and, therefore, their living conditions prevent us from appropriately mapping and randomly selecting subjects from - for example - census tracts. Consequently, demographic and drug use characteristics of this sample were compared to samples from other studies in Porto Alegre conducted by the same research group, which suggests that this sample's characteristics are similar and the participants are appropriate for piloting an HIV intervention targeted on indigent, urban, male cocaine users. ${ }^{43,44}$

Overall, $44.5 \%$ of the sample tested positive for HIV. Most studies conducted with IDUs and crack users in Brazil have had high seropositivity rates, which ranged from $28 \%$ to $44 \% .14,29,45$ This study confirms the high level of HIV and supports preventive approaches to decrease risky behaviors and risky situations for acquiring or transmitting the HIV virus. Of particular interest is the finding that the AIDS epidemic is increasing with the transmission of the HIV virus among young, uneducated heterosexual women. ${ }^{7}$ Anecdotal reports from focus groups conducted as part of this study suggest that the negotiation of safe sex by female sex partners of drug users may be an important factor to control the AIDS epidemic. This preliminary study was conducted with males - a sample that was already known to be exposed to HIV by drug use and potentially responsive to the intervention under test; should further research be continued with this technique, the research design might certainly be extended to include a group of women drug users as well.

Although the findings were not robust for the thought mapping/structured story intervention, they suggest that components of thought mapping might be useful if used with other interventions. The data show a significant increase in knowledge about HIV and AIDS in the experimental group when compared to the control group - particularly when confounders, such as participation in harm reduction programs, were controlled. However, although the intervention showed an improvement in the experimental group, it is not clear if this outcome would change if participants were not involved in needle exchange and harm reduction programs. Consequently, future research should include subjects who had no previous program contact, and possibly only seronegative cases, since many seropositive individuals know their serostatus, which assumes prior contact with pre- and post-test counseling.

The thought mapping/structured story intervention was successful in reducing the mean number of days of cocaine use in the experimental group, but this was probably due to the reduction in snorted cocaine as noted in Table 2 and 3. This finding suggests that the intervention only had some effect among the less critical users (cocaine snorters) compared with little or no effect on injectors and crack smokers. This is also noted in the increase in the use of these two drugs when the adjusted rates are examined in Table 3. At the same time, it seems that crack use was not responsive to the intervention, since there were no significant changes in the prevalence of crack use in the previous 30 days in either group. This finding suggests that the intervention did not reduce crack use among this population when compared to the controls. Consequently, future efforts should focus on tailoring both the NIDA Standard and the thought mapping/structured story interventions on these behaviors.

The intervention was successful in increasing condom use with heterosexual partners. It is possible that the sequence of thought mapping easily targets antecedents, behaviors and consequences of substance use, while "protected" sex does not include the physical discomfort of dependence and craving, which is associated with reduced cocaine use. It is important to note that medications were not provided to these patients to achieve a reduction in their drug use. 
The experimental intervention did not produce significant changes in the readiness to change drug and sex behaviors according to the URICA scale. There may be different explanations for this that range from scale validity to a lack of intervention efficiency, which is similar to other studies that used thought mapping. There are also different scales to measure stages and readiness to change for behaviors associated with drug use and sex. One of these scales, which has been validated in Porto Alegre studies is the" Stages of Change for Condom Use" scale, ${ }^{46}$ has been used in Brazilian Portuguese by our group and is currently being used in data collection with female crack users. Since it is more specific, we believe there would be more potential benefit in using a specific scale, instead of a general one.

\section{Study limitations and future directions}

One of the limitations of this study is the fact that this was a pilot study with no prior estimate of sample size. Therefore, we might have a loss of power for more potent analysis due to the small database available. However, feasibility was one of the key issues of the technique, and in that sense we could include and retain most of the study participants. Another limitation was that we could not draw a representative sample of cocaine/crack users of Porto Alegre, since they are not readily available for contact originated either from databases or individual programs. Therefore, we had to rely on social networks of currently known drug users eventually connected to prevention programs at different levels, and we don't know what the results would be if we could have departed from a more "naive" sample.

HIV and AIDS are increasing among drug abusers in Porto Alegre, despite current efforts. The strength of this project was the successful implementation and high follow-up rates, as well as potential directions for future research to develop tailored HIV preventive interventions. Although there were mixed findings from this preliminary study, continuing efforts in understanding the mechanisms of change and field testing interventions such as the thought mapping/structured story approach may prove efficacious in the future. If this officebased intervention provided by a mental health technician proves valid in future studies, drug users at the very end of the drug-using dimension may benefit from it and eventually diminish the already extreme burden that drug using individuals represent to the public health system of the country.

\section{Acknowledgments}

The authors wish to thank Mario Wagner, MD, for the statistical help, Claudia Szobot, MD, PhD, and Elisabeth Meyer da Silva, BA, MSc, for their suggestions and review of the preliminary forms of this manuscript.

\section{References}

1. Zaleski M, Laranjeira RR, Marques AC, Ratto L, Romano M, Alves HN, Soares MB, Abelardino V, Kessler F, Brasiliano S, Nicastri S, Hochgraf PB, Gigliotti AP, Lemos T. Guidelines of the Brazilian Association of Studies on Alcohol and Other Drugs (ABEAD) for diagnoses and treatment of psychiatric comorbidity with alcohol and other drugs dependence. Rev Bras Psiquiatr. 2006;28(2):142-8.

2. Inciardi JA. Crack Cocaine in the Americas. In: Monteiro MG, Inciardi JA, editors. Brazil-United States Binational Research. São Paulo: CEBRID; 1993. p. 63-75.
3. Lima ES, Bastos F, Telles PR, Desjarlais DC. HIV-1 Epidemiology among IVDUs in Rio de Janeiro, Brazil. VIII International Conference on AIDS, Amsterdam, 1992. 7-19, Poster PoC4265.

4. Lima ES, Bastos FI, Telles P, Friedman SR. HIV Infection and AIDS among Drug Injectors in Rio de Janeiro: perspectives and Unanswered Questions. Bull Narc. 1993;45(1):107-15.

5. Dunn J, Laranjeira RR, Da Silveira DX, Formigoni ML, Ferri CP. Crack cocaine: an increase in use among patients attending clinics in Sao Paulo: 1990-1993. Subst Use Misuse. 1996;31(4):519-27.

6. Ferri CP. Cocaína: padrão de consumo e fatores associados à procura de tratamento [tese]. Escola Paulista de Medicina, Universidade Federal de São Paulo. São Paulo; 1999.

7. Inciardi JA, Surratt HL, Pechansky F, Kessler F, von Diemen L, da Silva EM, Martins SS. Changing patterns of cocaine use and HIV risks in the south of Brazil. J Psychoactive Drugs. 2006;38(3):305-10.

8. Pechansky F, Diemen LV, Inciardi JA, Surratt H, DeBoni R. Fatores de risco para transmissão do HIV em usuários de drogas de Porto Alegre, Rio Grande do Sul, Brasil. Cad Saude Publica. 2004;20(6): 1651-60

9. Ferreira Filho OF, Turchi MD, Laranjeira R, Castelo A. Epidemiological profile of cocaine users on treatment in psychiatrics hospitals, Brazil. Rev Saude Publica. 2003;37(6):751-9.

10. Sanchez ZM, Nappo SA. Progression on drug use and its intervening factors among crack users. Rev Saude Publica. 2002;36(4):420-30.

11. Caiaffa WT, Mingoti SA, Proietti FA, Carneiro-Proietti AB, Silva RC, Lopes AC, Doneda D. Estimation of the number of injecting drug users attending an outreach syringe-exchange program and infection with human immunodeficiency virus (HIV) and hepatitis C virus: the AjUDE-Brasil project. J Urban Health. 2003;80(1):106-14.

12. Caiaffa WT, Proietti FA, Carneiro-Proietti AB, Mingoti SA, Doneda D, Gandolfi D, Reis AC; Epidemiological Study of Injection Drug Users in Brazil (AjUDE-Brasil Project). The dynamics of the human immunodeficiency virus epidemics in the south of Brazil: increasing role of injection drug users. Clin Infect Dis. 2003;37(Suppl 5):S376-81.

13. Mesquita F, Doneda D, Gandolfi D, Nemes MI, Andrade T, Bueno R, Piconez e Trigueiros D. Brazilian response to the human immunodeficiency virus/acquired immunodeficiency syndrome epidemic among injection drug users. Clin Infect Dis. 2003;37(Suppl 5):S382-5

14. Silva-Lima AF, Pechansky F, Genro VK. Soropositividade para HIV entre usuários de drogas em Porto Alegre: uma comparação entre usuários e não-usuários de drogas injetáveis. J Bras Psiquiatr. 2002;51(5):323-6.

15. Pechansky F. Modelo teórico de exposição para transmissão do vírus HIV em usuários de drogas. Rev Bras Psiquiatr. 2001;23(1):41-7.

16. Prochaska JO, DiClemente CC, Norcross JC. In search of how people change. Applications to addictive behaviors. Am Psychol. 1992;47(9):1102-14

17. Prochaska JO, DiClemente CC. Stages of change in the modification of problem behaviors. Prog Behav Modif. 1992;28:183-218.

18. Leukefeld CG, Pechansky F, Martin SS, Surratt HL, Inciardi JA, Kessler FH, Orsi MM, Von Diemen L, Meyer Da Silva E. Tailoring an HIV prevention intervention for cocaine injectors and crack users in Porto Alegre, Brazil. Aids Care. 2005;17(Suppl 1):S77-87.

19. Wechsberg WM, Macdonald BR, Dennis ML, Inciardi JA, Surratt HL, Leukefeld C, Farrabee D, Cottler LB, Compton WM, Hoffman J, Klein H, Desmond D, Zule B. The standard intervention for reduction in HIV risk behavior: Protocol changes suggested by the continuing HIVIAIDS epidemic. Bloomington, IL: Chestnut Health Systems/ Lighthouse Institute; 1997

20. Needle RH, Coyle SL, Normand J, Lambert E, Cesari H. HIV prevention with drug-using populations-current status and future prospects: introduction and overview. Public Health Rep. 1998;113(Suppl 1):4-18.

21. Knight K, Simpson DD, Dansereau DF. Knowledge mapping: A psychoeducational tool in drug abuse relapse prevention training. $J$ Offender Rehab. 1994;20(3/4):187-205.

22. Pitre U, Dansereau DF, Joe GW. Client education levels and the effectiveness of node-link maps. J Addict Dis. 2001;15(3):27-44.

23. Clark JJ, Leukefeld C, Godlaski T, Brown C, Garrity J, Hays L. Developing, implementing, and evaluating a treatment protocol for rural substance abusers. J Rural Health. 2001;18(3):396-406. 
24. Leukefeld C, Godlaski T, Logan TK, Warner B. Thought mapping: HIV behavioral intervention for drug abusers. Conference Proceedings: HIV Prevention in Rural Communities. Indianápolis, IN: Indiana University; 1999. p. 21-6.

25. Leukefeld C, Godlaski T, Clark J, Brown C, Hays L. Structured stories: reinforcing social skills in rural substance abuse treatment. Health Soc Work. 2002;27(3):213-7.

26. Inciardi JA, Surratt HL, Pechansky F. Redução de risco para HIV/ AIDS entre usuários de drogas: Um guia para trabalhadores e aconselhadores de saúde pública. New York: University of Delaware Research Center; 1999.

27. Gordon RS Jr. An operational classification of disease prevention. Public Health Rep. 2001;98(2):107-9.

28. Clark R, Harrelson GL. Designing Instruction That Supports Cognitive Learning Processes. J Athl Train. 2002;37(4 Suppl):S152-9.

29. Pechansky F, Von Diemen L, Kessler F, Hirakata V, Metzger D, Woody GE. Preliminary estimates of human immunodeficiency virus prevalence and validation of a questionnaire about risk behaviors for AIDS incidence among drug users. Cocaine abusers of Porto Alegre, Brazil. J Urban Health. 2003;80(1):115-26.

30. Pechansky F, Von Diemen L, Inciardi JA, Surratt H, DeBoni R. Fatores de risco para transmissão do HIV em usuários de drogas de Porto Alegre, Rio Grande do Sul, Brasil. Cad Saude Publica. 2004;20(6):1.651-60.

31. Pechansky F, Hirakata V, Metzger D. Adaptation and validation of a questionnaire about risk behaviors for AIDS among drug users. Rev Bras Psiquiatr. 2002;24(3):130-6.

32. Simoes AM, Bastos FI. [Audio Computer-Assisted Interview: a new technology in the assessment of sexually transmitted diseases, HIV, and drug use]. Cad Saude Publica. 2004;20(5):1169-81.

33. Kelly JA, St Lawrence JS, Hood HV, Brasfield TL. An objective test of AIDS risk behavior knowledge: scale development, validation, and norms. J Behav Ther Exp Psychiatry. 1989;20(3):227-34.

34. Surrat H, Inciardi JA. Developing an HIV Intervention for Indigent Women Substance Abusers in the United States Virgin Islands. J Urban Health. 2005;82(3 Suppl 4):iv74-83.

35. Oliveira M, Laranjeira R, Araujo RB, Camilo RL, Schneider DD. Estudo dos estágios motivacionais em sujeitos adultos dependentes de álcool. Psicologia: Reflexão e Crítica 2003;16(2):265-70.

36. Castro MM, Passos SR. Entrevista motivacional e escalas de motivação para tratamento em dependência de drogas. Rev Psiquiatr Clin. 2005;32(6):330-5

37. Carney MM, Kivlahan DR. Motivational subtypes among veterans seeking substance abuse treatment profiles based on stages of change. Psychol Addict Behav. 1995;9(2):135-42.

38. Velasquez MM, Carbonari JP, DiClemente CC. Psychiatric severity and behavior change in alcoholism: the relation of the transtheoretical model variables to psychiatric distress in dually diagnosed patients. Addict Behav. 1999;24(4):481-96.

39. Diggle PJ, Heagerm K, Liang Y, Zeger SL. Analysis of Longitudinal Data. Oxford: Oxford University Press; 2002.

40. Zeger SL, Liang KY. Longitudinal data analysis for discrete and continuous outcomes. Biometrics. 1986;42(1):121-30.

41. Aceijas C, Stimson GV, Hickman M, Rhodes T: United Nations Reference Group on HIV/AIDS Prevention and Care among IDU in Developing and Transitional Countries. Global overview of injecting drug use and HIV infection among injecting drug users. AIDS. 2004;18(17):2295-303.

42. Rodriguez CM, Marques LF, Touze G. HIV and injection drug use in Latin America. AIDS. 2002;16(Suppl 3):S34-41.

43. Pechansky F, Diemen LV, Genro VK. Presença de situações de risco para a transmissão de HIV em usuários de drogas não-injetáveis. Rev Psiq Clínica. 2001;28(3):157-9.

44. DeBoni R, Pechansky F. Age and gender as risk factors for the transmission of HIV in a sample of drug users of Porto Alegre, Brazil. Rev Bras Psiquiatr. 2002;24(3):137-40.

45. Pechansky F, Von Diemen L. Homens e mulheres usuários de drogas: semelhanças e diferenças na exposição ao vírus HIV em Porto Alegre. Rev ABEAD. 1998;1/2:15-25.

46. Meyer E, Carvalhal A, Pechansky F. Adaptation for Brazilian Portuguese of a scale to measure willingness to wear condoms. Rev Bras Psiquiatr. 2003;25(4):224-7. 